\title{
PROGRAMA LINHA DIRETA, O JORNALISMO CONTEMPORÂNEO ENTRE A CIDADANIA E A MERCADORIA
}

\author{
Linha Direta Program, \\ contemporary journalism between citizenship and merchandise
}

Daniel Barsi Lopes ${ }^{1}$

\section{Resumo}

O artigo analisa o programa Linha Direta, focando na auto-referenciação da atração televisiva como reestruturadora da cidadania dilacerada do público, empreendida na luta contra a violência visibilizada pelo programa. O trabalho contextualiza a violência urbana como cenário contemporâneo e procura investigar de que maneira se processa a atuação do programa em questão, se realmente em prol da cidadania e do interesse público, se regida pela lógica do espetáculo midiático - que se apropria dos fatos a partir da ótica do lucro e da busca de audiência e vê a notícia como mercadoria - ou se estabelecida por uma mediação, uma tênue linha pairando entre uma e outra posição.

Palavras-chave: Linha direta; Jornalismo; Cidadania; Mercadoria.

\section{Abstract}

The article analyzes the television program Linha Direta, focusing the television attraction as a citizenship rebuilder, carried on the struggle against violence seen by the program. The work make a context of the urban violence as a contemporary scenery and tries to investigate how is the acting process of the program, if it is according to the citizenship and the public interest or if it is orientated by the mediatic show - which treats the facts from the view of profit and audience and understands the news as merchandise - or if it is determined by a mediation, just a weak line between one and the other position.

Keywords: Linha direta; Journalism; Citizenship; Merchandise.

\footnotetext{
Daniel Barsi Lopes é publicitário, mestrando, aluno do Programa de Pós-Graduação em Ciências da Comunicação na Universidade do Vale do Rio dos Sinos - Unisinos. Bolsista Capes - Coordenação de Aperfeiçoamento de Pessoal de Nível Superior e membro do grupo de pesquisa PROCESSOCOM - Processos comunicacionais: epistemologia, midiatização, mediações e recepção. Bacharel em Comunicação Social pela Universidade Federal do Ceará - UFC. e-mail: daniel_barsi@yahoo.com.br
} 


\section{Introdução}

As pesquisas que se dedicam à análise e à apreensão da temática da violência na mídia têm extrema relevância para o estudo científico, visto que envolvem dois dos maiores fenômenos de nossa atualidade: a proliferação desenfreada da violência urbana e os meios de comunicação de massa em seu intenso processo de midiatização. ${ }^{2}$ A maneira como ambos os fenômenos se interpenetram, gerando um tratamento peculiar dado à violência urbana pelos meios de comunicação hodiernos - com seu alto poder de penetração nas massas - e as conseqüências daí decorrentes são de grande importância para a sociedade.

O objeto que será tratado de forma mais detida no espaço deste artigo é o programa Linha Direta, exibido semanalmente pela Rede Globo desde 1999. O Linha Direta construiu para si uma imagem de programa de "utilidade pública", pois está a serviço da sociedade, em busca de solucionar os casos que a justiça e a polícia, por sua "lentidão e incompetência", não foram capazes de resolver. A denúncia, o fato do telespectador poder denunciar por telefone - sem ser identificado - o paradeiro do foragido é o grande trunfo do programa, o que, para a emissora, é o diferencial em relação aos outros, que "mostram por mostrar", sem nenhum comprometimento com a população, sem dar a oportunidade de participação a esta sociedade, “ávida por justiça”. O Linha Direta se coloca, então, como um verdadeiro reestruturador da cidadania perdida de seus telespectadores.

O que temos visto nas últimas décadas, no entanto, é uma intensa corrida em busca do espetáculo de imagens por parte dos meios de comunicação, especialmente pelo campo jornalístico. Seria absurdo generalizar toda a prática jornalística tomando como base este tipo de ação, mas não podemos desconsiderar a penetração deste tipo de discurso pautado no sensacionalismo ${ }^{3}$ em nossa sociedade midiatizada contemporânea. Bourdieu (1997) nos fala da banalização que sofrem os assuntos ao serem expostos pelos veículos midiáticos, especialmente na televisão, convertendose em verdadeiras mercadorias, em busca do lucro obtido com os pontos de audiência. É nesse cenário que, muitas vezes, as imagens de exceção, como as da violência, podem aparecer com um fim em si mesmo e não como algo para se chegar a algum lugar, como um instrumento que possibilite algum tipo de emancipação e de mudança na ordem social exclusivista e desigual.

Para nos determos de forma mais ampla sobre esta questão e refletirmos acerca da posição do Linha Direta como um instrumento de cidadania ou um mero artefato de mercadoria, faz-se urgente um resgate e uma análise sobre o fenômeno o qual o programa se dedica em sua abordagem: a problemática da violência em nossa sociedade.

\section{A violência urbana como cenário contemporâneo}

O planeta vem passando por intensas transformações desde as duas últimas décadas do século XX. A queda do muro de Berlim, em 1989, pode ser emblemática da entrada em uma nova era, em um novo período, onde nossos referenciais de ser e estar no mundo passam por intensas reconfigurações. Uma série de rupturas se sucedia ao passo que novos tipos de relações eram produzidos. Enfim, segundo Tavares dos Santos, "alguma coisa estava acontecendo no mundo." Este autor completa, afirmando que "mudaram [...] as configurações do social e das questões sociais nas últimas três décadas" (SANTOS, 1999, p. 19).

Com a série de eventos proporcionados pelo desencadeamento da globalização, dos

\footnotetext{
2 'Tendência à ‘virtualização’ ou telerrealização das relações humanas, presente na articulação do múltiplo funcionamento institucional e de determinadas pautas individuais de conduta com as tecnologias de comunicação (SODRÉ, 2002, p. 21). Antônio Fausto Neto, em aula ministrada no Programa de Pós-Graduação em Ciências da Comunicação da Universidade do Vale do Rio dos Sinos, em 17 de maio de 2006, destaca que este é um conceito em construção, que resulta do avanço do fenômeno das mídias em nossa cotidianidade. Estas são apenas algumas das várias considerações que podemos fazer acerca do conceito de midiatização.

3 Angrimani (1995, p. 13) lança mão do dicionário Aurélio para definir sensacionalismo: "S.m. 1. Divulgação e exploração, em tom espalhafatoso, de matéria capaz de emocionar ou escandalizar". Também acerca desta palavra, o dicionário eletrônico Houaiss no diz que sensacionalismo significa: "uso e efeito de assuntos sensacionais, capazes de causar impacto, de chocar a opinião pública, sem que haja qualquer preocupação com a veracidade."

4 Fala de José Vicente Tavares dos Santos em aula ministrada na disciplina "Sociologia da Conflitualidade", no Programa de Pós-Graduação em Ciências Sociais da Universidade Federal do Rio Grande do Sul. 08 de maio de 2007.
} 
processos informatizados, do fortalecimento do capitalismo selvagem, mudanças estruturais acontecem em nossa sociedade de transição do século XX para o século XXI. A "era do globalismo" (IANNI, 1996) traz à tona uma sociedade formada tanto pela homogeneização quanto por profundas contradições sociais, por desigualdades e exclusões. Segundo Ianni (1992, p. 51):

Trata-se de uma totalidade histórico-social diversa, abrangente, complexa, heterogênea e contraditória, em escala desconhecida. Esse é o horizonte no qual se desenvolvem a interdependência, a integração e a dinamização, bem como as desigualdades, as tensões e os antagonismos característicos da sociedade mundial.

Essa sociedade global, ainda em fase de desenvolvimento - o que dificulta seu pronto entendimento - trouxe uma série de alterações e reformulações nas vidas dos sujeitos que dela participam. As relações de sociabilidade se reconfiguram; as redes de solidariedade se desagregam; o desenvolvimento do capitalismo alicerça a segmentação social; a progressão contínua da mundialização da cultura fortifica o imperialismo, acarretando massificação, individualização, ocidentalização e desterritorialização; as inovações tecnológicas são acompanhadas da precarização do trabalho e do desemprego. Ou seja, todos esses processos efetivados pela sociedade global contemporânea são "marcados pelo incremento não apenas das diferenças mas também das desigualdades sociais e do mecanismo de seleção-exclusão social”' (SANTOS, 1994, p. 82).

O fenômeno da globalização e o desenvolvimento do capitalismo são também a solidificação e a imposição cada vez mais explícita de uma cultura do consumo, uma cultura que utiliza a mídia para disseminar valores onde o que importa e o que dignifica e diferencia os indivíduos é o consumismo. Como os efeitos da globalização e o aquecimento da economia não são positivos e benéficos para todos e o aumento das desigualdades se dá de forma cada mais veemente, uma parcela considerável - para não dizer a grande maioria - da população fica de fora desse restrito grupo que pode se regozijar com o poder de compra que dá acesso aos bens de consumo que com tanta insistência são exibidos nos meios de comunicação. Esse contingente, sentindo-se excluído da possibilidade de comprar no "Magazine Luiza" ${ }^{5}$ ser feliz, procura utilizar-se de uma contralinguagem como uma maneira de adquirir a visibilidade que lhes é negada constantemente pela sociedade.

Todos esses movimentos dão forma a um processo de "desfiliação" (CASTEL, 1998), ou seja, a ausência de inserção dos indivíduos em estruturas que tenham significação social. Segundo Pais (2001), antigamente existia uma previsibilidade de destino, que hoje não existe mais. A ausência de destino, de placas, de direções coloca o jovem em uma encruzilhada, pois não há mais o trilho a ser percorrido, provocando, então, a ruptura dos laços sociais.

Esse esgarçamento nas relações entre os indivíduos se faz sentir também por meio do rompimento dos laços de confiança e reciprocidade nas instituições socializadoras, tais como a família, a escola, a comunidade, etc., fazendo com que "sobre" muitos elementos para o Estado socializador que, também vítima de um processo de desgaste de suas instituições, não dá conta de abarcar, ocasionando o constante e assustador aumento de contingentes populacionais abandonados à própria sorte.

Como conseqüência de todos esses fatores e por que não dizer, também, como retroalimentador desses processos - está a exacerbação do fenômeno da violência. Dentre essas novas questões sociais provocadas por todas essas alterações nas formas dos indivíduos se relacionarem entre si e se relacionarem com o mundo, "os fenômenos da violência adquirem novos contornos, passando a disseminar-se por toda a sociedade" (SANTOS, 1999, p. 21).

A violência e a criminalidade surgem como elementos de uma espécie de resposta dos despossuídos à sociedade, como um artefato de visibilidade, de proporcionar luz às suas causas, aos seus anseios, à sua revolta com a exclusão e a desigualdade sociais. A violência converte-se em um ato de comunicação, em um protesto contra "as grandes promessas da modernidade [que] permanecem incumpridas ou [cujo] o seu cumprimento redundou em efeitos perversos" (SANTOS, 2000, p. 23). Todas essas formas de expressão da violência passam, então, a fazer parte de

5 O Magazine Luiza, loja de eletrodomésticos e móveis que tem extensa penetração publicitária na televisão brasileira, tem como slogan "vem ser feliz", numa atitude clara de que a felicidade está ligada ao poder de compra e ao consumismo. 
nosso cotidiano, a entranhar-se por todos os espaços de nossas cidades, convertendo-se em um verdadeiro caos urbano que amedronta e domina a população em nosso país.

O medo da violência e da criminalidade chegou a tal ponto que cercas elétricas, muros altíssimos, circuitos internos de TV, sistemas de alarme, enfim, toda uma parafernália tecnológica é utilizada para dar segurança aos habitantes das cidades em suas rotinas de vida, mesmo que sua privacidade já não seja a mesma de antes e que esses indivíduos se sintam verdadeiros prisioneiros até mesmo dentro de suas próprias casas. Já as classes mais desprovidas financeiramente, que muitas vezes sequer têm moradia própria (imagine recursos para investir em segurança), parecem realmente fadadas à convivência de perto com a violência, tendo ela como vizinha. Especialmente porque, quanto mais periférico é o bairro, mais esquecido ele o é pelo Estado e pela sociedade e, conseqüentemente, mais suscetível ao fenômeno da violência estão seus moradores. Até mesmo os artifícios da "sociedade vigiada" são colocados menos em prática quanto mais os bairros vão se afastando dos centros comerciais e estratégicos das cidades.

O que podemos refletir acerca desse cenário violento que enunciamos acima é que os crescentes índices de criminalidade fazem com que da hora em que acordamos até a hora de deitarmos em nossas camas para dormir tenhamos o medo como nossa companhia constante, o mesmo medo que faz com que verdadeiras reviravoltas em nossas vidas sejam feitas, privando-nos de nosso bem mais valioso - a liberdade -, com o intuito de tentar nos proteger da violência urbana.

Valendo-nos do importante conceito de violência como "cidadania dilacerada" (SANTOS, 2002), vejamos agora como a cidadania, também ela esfacelada pela imposição das políticas neoliberais, pela desestruturação das relações sociais e pela quebra de confiança nas instituições do Estado como conseqüência dos mesmos movimentos vistos acima -, pode ser atrelada aos meios de comunicação de massa, na configuração de uma cidadania midiatizada, de um combate ao fenômeno da violência não mais empreendido pelo poder público, mas liderado principalmente pela televisão.

\section{A cidadania midiatizada e o combate à violência}

A partir das transformações - trazidas pelo advento da urbanização, da globalização e da midiatização - ocorridas nas formas dos indivíduos se relacionarem entre si e nas suas formas de interações com os meios de comunicação e com as instituições, tem-se, como um dos vários efeitos propiciados por estes deslocamentos, que a cidadania, o sentimento de ser cidadão, de pertença a uma comunidade, antes praticados pelas relações "face-a-face", pelas identidades locais, pelas interações territorializadas e, principalmente, pela atuação do Estado, passam a ser, também, intercambiadas pela mídia. Não podemos deixar de perceber em nossa sociedade contemporânea o fato de que o fenômeno da midiatização parece afetar todas as práticas sociais existentes, passando a fazer parte de nossa cotidianidade, muitas vezes, segundo se observa em Mata (1999), atuando como mediação entre os sujeitos e as instituições.

Com a globalização e as inovações tecnológicas - e as conseqüentes transformações nas formas de interações acarretadas por essas inovações - as instituições clássicas acabam perdendo parte de seu peso. Dá-se, então, segundo Carvalho (2002, p. 225), "a redução do papel central do Estado como fonte de direitos e como arena de participação". Ainda segundo Mata (2000), percebemos, com o processo de midiatização, a substituição das instituições oficiais - partidos, órgãos governamentais, instâncias judiciais - como o lugar para a representação cidadã, pelos meios massivos de comunicação. É bastante significativo, para a discussão acerca desta temática, que atentemos ao fato de que para muitas pessoas, atualmente, tornase mais simples e, principalmente, mais rápido recorrer ao sistema midiático ${ }^{6}$ - televisão, rádio, jornais, Internet - na busca de resoluções para uma série de questões do que, por exemplo, procurar

\footnotetext{
6 Para confirmar isso basta percebermos na Internet e em várias revistas e jornais de circulação nacional - especialmente em seções do tipo "Seus Direitos" ou "Ajuda" - a quantidade de casos de insatisfação e cobrança de resoluções, por parte dos leitores, em relação a bens e serviços que são agilizados e/ou resolvidos a partir da intervenção do veículo midiático. No rádio, práticas como essas são até mais antigas. Já a televisão, devido a custos e operacionalidades, não tem a mesma tradição, como o rádio, em atuações comunitárias.
} 
ajuda em órgãos oficiais, tais como Procon, ${ }^{7}$ Decon, ${ }^{8}$ etc. (no caso de soluções para problemas relacionados ao consumo de bens e serviços). É nesse cenário, então, que os indivíduos recorrem ao Linha Direta em busca de solução para crimes mal ou sequer resolvidos pela justiça. Sobre este ponto, faz-se necessário, então, que resgatemos Orozco (2004, p. 11), quando esse autor questiona "Cómo se está constituyendo el sujeito individual y colectivo como ciudadano de um pais e del mundo, cuando la mayor parte de su constitución está mediatizada por sus múltiples vínculos com médios y tecnologias de información?"

Utilizando-nos do aporte teórico oferecido por Mata (2006) a este respeito, temos que "os meios proclamam-se como o espaço para exercer o direito à cidadania. $\mathrm{O}$ espaço que supre a carência de cidadania". Corroborando com o sentido evidenciado por Mata, a perspectiva de Bucci (2004, p. 33) é a de que "o que não é visível não existe. $O$ que não tem visibilidade não adquire cidadania". E completa afirmando que:

A esfera pública da sociedade de consumo, a sociedade em que vivemos, tem a sua esfera pública privatizada, na qual atributos da cidadania se convertem em bens de consumo e na qual a lógica do espetáculo absorve e comanda a organização e a disposição dos conteúdos. (BUCCI, 2004, p. 41).

É nesse cenário de uma cidadania que necessita da visibilidade pública oferecida pela mídia para ser posta em prática onde se insere o programa Linha Direta. O programa, que normalmente exibe toda semana (às quintas-feiras) dois casos de crimes nos quais os acusados (ou parte deles) estão foragidos, propõe-se a ocupar um lugar além do de simples meio de comunicação e divulgador de informações. Ele quer para si um lugar de mediador, de interlocutor entre a sociedade e a justiça, colocando-se, em muitos casos, acima da própria justiça, fazendo o papel dela, o papel que, segundo o discurso do programa, ela havia deixado de fazer.

São $415^{10}$ fugitivos exibidos no programa e capturados por denúncia dos telespectadores ${ }^{11} \mathrm{em}$ 8 anos e meio de atuação da atração na grade televisiva brasileira. Quatrocentas e quinze pessoas as quais o programa julga-se responsável, juntamente com a participação da sociedade, pela captura. Esse número tem destaque na página do Linba Direta na Internet e é repetido exaustivamente pelo apresentador do programa. Domingos Meireles ${ }^{12}$ também dedica especial atenção às prisões dos acusados denunciados, informando com riqueza de detalhes - inclusive com tomadas do local onde o fugitivo estava ao ser capturado - o processo empreendido pela polícia logo após o telefonema denunciativo feito pelo telespectador à produção do programa. Todos esses artifícios servem como uma espécie de mostruário, que atesta a eficácia da proposta do Linha Direta, que ratifica essa "cumplicidade" entre a Rede Globo, o programa e o telespectador na resolução do problema da violência urbana e na reconstrução da cidadania dilacerada.

Mas de que maneira se dá esse combate à violência e esse exercício de cidadania empreendidos pelo Linha Direta? A partir de quais lógicas são esses assuntos - os crimes malresolvidos pela justiça, as famílias envolvidas nos casos, as reconstruções dos delitos, a exposição dos indivíduos em rede nacional, a defesa dos acusados, etc. - expostos no programa? Será que na luta desenfreada pelo lucro, obtido a qualquer recurso, a televisão não estaria transformando este movimento de recomposição da cidadania num artefato de busca de audiência, num instrumento de acúmulo de capitais, enfim, em mercadoria?

\footnotetext{
Programa de Defesa do Consumidor.

Programa de Proteção e Defesa do Consumidor.

9 Conferência de Maria Cristina Mata em aula inaugural do ano letivo no Programa de Pós-Graduação em Ciências da Comunicação da Unisinos, 29 de março de 2006.

10 Dados do dia 09 de novembro de 2007, obtidos no site do programa: www.globo.com/linhadireta

11 Em alguns casos, os fugitivos foram presos pela polícia antes mesmo de o programa ir ao ar, mas a produção da atração se julga responsável pela captura da mesma maneira, pois, para o Linha Direta, a denúncia pode ter sido feita já a partir das chamadas do programa nos intervalos comerciais da Globo. Há, também, segundo a direção do Linha Direta, os casos em que o acusado se entrega a polícia ao ver as chamadas com sua história dias antes do programa ir ao ar.

12 Domingos Meireles apresenta o Linha Direta desde o segundo ano de exibição do programa, logo após o afastamento de Marcelo Rezende da atração.
}

Rev. Estud. Comun., Curitiba, v. 8, n. 17, p. 235-246, set./dez. 2007 


\section{Linba Direta e as lógicas do espetáculo midiático}

O conceito de espetáculo que cunhamos aqui diz respeito à maneira sensacionalista com que um determinado assunto pode ser abordado pela mídia, ganhando destaque e espaço nos meios de comunicação. É dada aos assuntos uma roupagem de espetáculo, de show, desvirtuando a abordagem crítica acerca do tema, que, a partir de então, passa a ter uma análise superficial do seu conteúdo, sendo destacados somente aqueles pontos que possam causar polêmica, "estardalhaço". O assunto acaba por ser banalizado pela extensa exposição nos veículos midiáticos.

Acerca do jornalismo-espetáculo da atualidade, faz-se importante resgatar Barros e Silva (apud BORELLI; PRIOLLI, 2000, p. 74), quando dizem, acerca desse tema, que: "atrofia dos assuntos de relevância pública, espetacularização da vida íntima, ênfase no showbiz e sentimentalismo exacerbado [...] "são recursos estratégicos, legítimos e desejáveis quando a notícia se torna exclusivamente refém das oscilações de audiência”. Nesse sentido, Kellner (2006, p. 122) parece corroborar essa visão, quando nos diz que a "produção de notícias também está sujeita à lógica do espetáculo, em uma época de sensacionalismo, tabloidização, escândalos e contestações políticas". Bourdieu (1997, p. 22) completa, afirmando que "o sangue e o sexo, o drama e o crime sempre fizeram vender, e o reino do índice de audiência devia alçar à primeira página, à abertura dos jornais televisivos”.

Para contextualizarmos o surgimento do Linha Direta no cenário televisivo nacional, temos que voltar a meados da década de noventa, mais especificamente à época do nascimento do Plano Real e da fase da "multiplicidade da oferta" (BRITTOS, 2000) na televisão brasileira.

O plano econômico do governo de Itamar Franco, que trouxe como conseqüência o controle da inflação e a estabilização da economia, também teve grande responsabilidade pelo surgimento de um novo público na recepção televisiva, público esse que passou a ter acesso à televisão como meio de comunicação a partir desse novo panorama econômico criado em seu governo. Com o controle da inflação e a estabilização da economia, houve uma maior facilidade das camadas economicamente menos favorecidas em poderem adquirir, pela primeira vez, determinados aparelhos eletroeletrônicos, dentre eles, destaca-se a televisão.

Em 1993, existiam cerca de 31 milhões de aparelhos em uso. De 1994 a 1998, foram vendidos cerca de 28 milhões de aparelhos, quase dobrando o número existente em 1993. E o fato mais significativo é que, desse total, cerca de 6 milhões foram comprados por famílias que estavam adquirindo sua primeira televisão. Esses novos telespectadores estão localizados nas classes D e E. (BORELLI; PRIOLLI, 2000, p. 148).

A partir de então, uma nova parcela da população tem, pela primeira vez, acesso à televisão. ${ }^{13}$ Uma parcela econômica e culturalmente menos favorecida. Faz-se interessante, também, a partir das perspectivas oferecidas por esta nova fase no cenário receptivo brasileiro, refletir sobre as novas configurações que se processam nas relações entre esses públicos e a televisão, quando a assistência muitas vezes migra da praça onde está instalado o aparelho-receptor para a contemplação da comunidade, ou da casa do vizinho, ${ }^{14}$ para a assistência no próprio lar, fazendo com que os telespectadores tenham mais oportunidades, eles mesmos, de determinação dos canais a serem consumidos, em vez de assistirem ao que foi determinado pelo controlador da TV da praça ou pelo vizinho. Corroborando com esses movimentos de transformações, o desenvolvimento das inovações tecnológicas e a conseqüente chegada das TVs por assinatura, que têm uma programação mais diferenciada e segmentada, já que atuam para um público mais exigente e de maior poder aquisitivo, fazem com que haja uma migração de camadas das classes ${ }^{15} \mathrm{~A}$ e B da televisão aberta para os canais pagos.

13 É importante ressaltar que o governo dos militares teve, também, grande participação na disseminação do uso do aparelho-receptor, na década de setenta.

14 Nas cidades de interior, especialmente na Região Nordeste do país, ainda hoje se observa a assistência de TV nas praças e/ou na casa de vizinhos. Há cerca de dez anos essa característica era ainda mais forte.

15 É importante deixarmos claro que a palavra classe aqui está relacionada ao uso do substantivo pelo IBOPE - Instituto Brasileiro de Opinião Pública e Estatística. Ou seja, classe como nos referimos aqui está vinculada às categorizações hierárquicas do IBOPE feitas pela pesquisa. Nessas pesquisas, é avaliado o contexto socioeconômico dos indivíduos, com base nas informações de escolaridade, profissão, posse de bens, dentre outros. A partir da análise dos dados advindos com a pesquisa, é feito um perfil do telespectador, então distribuído em categorias, classes, que podem ser A, B, C, etc. 
Esses fatores, em conjunto, apresentam dados novos à realidade para a televisão brasileira. Há, a partir de então, uma nova audiência televisiva, composta por mais pessoas das classes $\mathrm{C}$ e D - que muitas vezes não tiveram acesso à educação de qualidade, cultura e outras formas de entretenimento - e por menos pessoas das classes A e B. E as emissoras de televisão aberta têm que se adaptar a esse novo panorama receptivo, se não quiserem perder audiência e, conseqüentemente, dividendos.

As emissoras menores, com uma grade de programação menos estável do que a da Rede Globo, portanto mais flexível para mudanças, resolveram apostar logo nesse novo mercado e "usá-los como estratégia de apelo para garantir uma quantidade significativa de audiência" (RONDELLI, apud MENDONÇA, 2002, p. 62). Fazendo uma síntese desse cenário televisivo, atravessado por todos os fenômenos ordenadores de uma lógica ainda mais focada no lucro, Oliveira (2003, p. 64) afirma que:

Num mercado concorrencial, mais curto, os 'efeitos perversos' provocados pela 'guerra das audiências', a preceito da busca incessante de 'shares' são evidentes. Se o 'produto' não 'vende' o fecho é uma ameaça, paira o pânico do desemprego que contribui para as concessões deontológicas e éticas, cometidas [...] em nome da sobrevivência.

A exacerbação do grotesco que se tornou recorrente na mídia de massa pode acabar filtrando da dimensão pública as questões mais relevantes para o debate da sociedade, seja pelo agendamento de temas que, muitas vezes, prestam-se a estimular a lassidão na periferia, seja a partir da parcialidade expressada por abordagens tendenciosas. E no bojo desses movimentos vão surgindo nas emissoras brasileiras programas do gênero violento, ${ }^{16}$ além de programas ditos de "variedades" ou "femininos", no horário vespertino, ${ }^{17}$ que dedicam um espaço para a "sociedade", para a "denúncia", enfim, para a abordagem de forma espetacularizada da criminalidade. Segundo Capparelli e Lima (2004, p. 100), "o grotesco passou a assistencialismo, sensacionalismo, linguagem chula e show de variedades". Brittos (2006, p. 24) completa esta argumentação quando afirma que na fase da multiplicidade da oferta:

A busca da captação rápida do consumidor, já que as dinâmicas de fidelidade deste para com os distribuidores e produtores é cada vez mais tênue, tem promovido a expansão de critérios de formatação de produtos de fácil assimilação, o que tem sido chamado, no caso dos mercados televisivos, de popularização das programações.

A Globo demorou cerca de três ou quatro anos para se enquadrar de forma mais explícita a essas transformações midiáticas advindas com o Plano Real. Durante esse tempo, viu o programa do apresentador Carlos Massa, o Ratinho, perder em audiência somente para a novela das $21 \mathrm{~h}$ e para o humorístico Casseta e Planeta. Em 1999 - após um teste com o programa feito no ano anterior num quadro do Fantástico, no qual o apresentador Marcelo Rezende fez uma longa entrevista com o "maníaco do parque" - a emissora põe no ar o Linha Direta.

Para compreendermos o funcionamento do Linha Direta e seu estreito vínculo com as lógicas do espetáculo televiso da atualidade, temos que nos concentrar naquilo que é seu diferencial em relação aos outros programas do gênero policial, ${ }^{18}$ naquela que é a característica fundamental da atração, o cen-

16 Ivana Bentes, em palestra ministrada no IX Seminário Internacional da Comunicação, promovido pela PUCRS, afirma que a violência constitui-se, na atualidade, por si só, em um gênero midiático. Porto Alegre, 8 de novembro de 2007.

17 O horário vespertino é dedicado, em muitas emissoras, aos programas de variedades, mais voltados para o público feminino. São programas que têm como atrações a presença de artistas, cabeleireiros, estilistas, culinaristas e um grande espaço dedicado às fofocas do mundo televisivo.

18 É importante que tenhamos em mente, desde já, que a Rede Globo não inclui o Linha Direta no gênero de programas policiais, mas enquadra-o como um programa prestador de um serviço de utilidade pública. Como ele mostra casos policiais mal ou ainda não resolvidos pela justiça, exibindo reconstituições de crimes, depoimentos de profissionais e de familiares envolvidos, laudos periciais, dados do Ministério Público, enfim, como ele se utiliza de todos esses artefatos, seguindo um perfil semelhante ao de seus predecessores nos Estados Unidos e na Inglaterra, não vemos restrição (e nem preconceito) quanto ao uso, no espaço deste artigo, da terminologia "policial", apesar de termos claro que o Linha Direta se configura complexo demais para ser enquadrado somente como um gênero desse tipo, estando ao programa da Globo imbricado uma série de outros fatores.

Rev. Estud. Comun., Curitiba, v. 8, n. 17, p. 235-246, set./dez. 2007 
tro das atenções, tanto por parte dos produtores do programa como por parte dos telespectadores: $a$ esquete-reportagem. ${ }^{19}$

As esquetes são pequenas histórias que fazem uma retrospectiva da vida da vítima e do acusado, com destaque para a primeira, até a época que antecede o crime, atingindo o clímax no momento em que este é exibido. As esquetes são narradas em off e algumas vezes interrompidas pela fala do apresentador do programa, em sua maioria antecedendo ao intervalo comercial, para fazer um comentário do que está por vir na história, como uma tentativa de prender a atenção do telespectador e fazê-lo aguardar ansiosamente pelo próximo bloco. Para isso são utilizados recursos de impacto narrativos, como frases nas quais se ouve "ele ainda não sabe, mas este é o dia de sua morte" ou "é a última vez que ela vê o marido."

A partir das esquetes, o programa empreende aquilo que Bourdieu (1997) denomina de "ocultar mostrando", ou seja, o Linha Direta proporciona visibilidade, enfatiza determinados acontecimentos em detrimento de outros, que são diminuídos, deixados em segundo plano, como até mesmo a possibilidade de defesa por parte do acusado, que tem por vezes silenciadas e/ou diminuídas suas chances de se defender. O que adquire importância para a produção e é, então, selecionado para ir ao ar é aquilo que pode chocar, que tem condições de emocionar, de criar uma reação imediata nos telespectadores. "O princípio de seleção é a busca do sensacional, do espetacular. A televisão convida à dramatização, no duplo sentido: põe em cena, em imagens, um acontecimento e exagera-lhe a importância, a gravidade, e o caráter dramático, trágico" (BOURDIEU, 1997, p. 25).

Outra característica presente no Linha Direta que vai diretamente ao encontro dos lógicas da notícia como mercadoria é a velocidade com que os fatos são mostrados e a absoluta falta de contextualização dos assuntos abordados a partir das esquetes. A incessante busca pela novidade, a concorrência desenfreada pela notícia - e pelo lucro obtido com a venda dela - ocasiona o que se chama de fait-diver (BOURDIEU, 1997), que é a notícia superficial, descolada de seu contexto gerador. No Linha Direta, um programa que se propõe como um instrumento na luta contra a violência, esse fenômeno, em momento algum, é discutido pela atração. Suas raízes, sua estrutura, suas formas de atuação na sociedade, as maneiras preventivas (e não apenas punitivas) de se atacá-lo, nada disso é levado à discussão pública, nenhum conhecimento mais aprofundado acerca do fenômeno da violência é transmitido aos telespectadores do Linha Direta, onde reina a análise leviana, rápida, onde o que conta é o número de facadas e de tiros, ou quantos filhos a mulher deixou órfãos, ou, ainda, quantos mil reais a mandante de determinado crime ganhou com o seguro do marido assassinado. O que ganha importância, no Linha Direta e em tantos outros programas que se regem pela lógica do espetáculo e que vêem o jornalismo como mercadoria, são os números, as quantidades, o que pode chocar.

Segundo Oliveira (2003, p. 68), "estamos a ser levados para um culto da superficialidade e da imediaticidade pela forma como os 'media' nos tentam dar notícia, contar estórias, sobre os fenômenos mais complicados da sociedade atual". Completando a linha de raciocínio acerca deste assunto, Duarte (2004, p. 60) afirma que “dificilmente $[\mathrm{a}$ TV] poderá abordar esses conteúdos em profundidade, porque assim feriria princípios muito internalizados da gramática televisiva e [...] também porque a densidade de imagens, a fragmentação de texto e o tempo impediriam".

A mídia seleciona, sintetiza, reformula os acontecimentos em função das regras de mercado, da ideologia e das rotinas de trabalho que lhe são próprias. [...] Por todas estas razões, só uma parcela dos crimes que, de fato, ocorrem são noticiados; [...] só as fases mais 'emotivas' de cada crime têm espaço na mídia; [...] só determinadas explicações para o sucedido são divulgadas. ${ }^{20}$

19 O termo esquete-reportagem, utilizado aqui, vem do livro de Mendonça (2002). No dicionário eletrônico Aurélio, a palavra esquete aparece vinculada ao teatro e significa "pequena cena de revista teatral, ou de programa de rádio ou televisão, quase sempre de caráter cômico". O reportagem, adicionado à palavra original por meio de hífen, vem justamente para diferenciar o uso da expressão no programa da Globo, visto que no Linha Direta a esquete, essa "pequena cena", surge mais como uma reconstituição, com um tom muito mais jornalístico, onde não há espaço para a comicidade. Para evitar a repetição do termo neste artigo, e squete, esquete-reportagem e simulação serão utilizados aqui indistintamente.

${ }^{20}$ Artigo não assinado na revista "Crime e TV”. Revista do ILANUD - Instituto Latino-Americano das Nações Unidas para a Prevenção do Delito e do Delinqüente, n. 13, p. 12-13, 2001. 
Em 2007, as transformações que todos os anos atingem o programa em sua reestréia na grade da Rede Globo em abril - mas que anteriormente se restringiam a pormenores como abertura, cenários, voz do locutor, etc. - foi mais intensa, ocasionando, pela primeira vez desde a estréia do programa, em 1999, a presença de convidados no palco, interagindo com o apresentador Domingos Meireles. O Linha Direta, então, traz ao estúdio a "fala dos especialistas". Segundo Bourdieu (1997), os convidados para a televisão são sempre os mesmos, são pessoas "preparadas para o mundo da TV", profissionais com a capacidade de falar sobre os assuntos de maneira fácil, superficial e veloz, com objetivos de pronto entendimento por parte dos telespectadores, indo ao encontro das lógicas da televisão massiva.

Os convidados são especialistas de áreas correlatas aos assuntos pautados no Linha Direta, personalidades que falam o óbvio, que simplesmente não acrescentam nada de novo ao debate acerca do problema da violência urbana em nossa sociedade. O que se vê no estúdio do programa são as mesmas discussões de sempre - as mesmas perguntas e as respostas semelhantes - sendo requentadas e levadas à assistência do telespectador. Machado (1999, p. 142-158 ) alicerça esta posição quando nos diz que:

Grande parte dos debates promovidos sob essas circunstâncias é marcado pelo ritmo ferrenho do cronômetro, com perguntas e respostas desferidas à queima-roupa, sem intervalos para pausas, hesitações ou reflexões. A possibilidade de um real diálogo filosófico, nem é preciso dizer, depende muito da conquista de um outro timing televisual, mais livre e mais fluido do que aquele imposto à televisão pela metralhadora de cortes dos spots publicitários.

Os especialistas estão ali para fortificar a credibilidade do programa, para somar à autoridade do real exibido nas cenas da esquete-reportagem. O diálogo empreendido entre o especialista e o apresentador não dá lugar ao improviso, ao inesperado, à fluidez inerente a uma discussão com conteúdo e tensionamentos. Um está lá simplesmente para corroborar a posição e a fala do outro, como se tudo o que está sendo dito ali já estivesse previamente acordado em um ensaio feito nos bastidores, de modo a garantir que nada escape às lógicas televisivas e aos artefatos básicos dos debates midiatizados. Sustentando essa reflexão, Oliveira (2003, p. 67) afirma que:

Os media, sobretudo os audiovisuais, servemse dos 'experts' muitas das vezes para dar legitimação à orientação de 'agendamento' por eles organizado. [...] São as novas 'vedetes' do opinionismo, integradas na estratégia da 'mercadorização dos media'.

Mais interessante ainda é perceber, a partir desses convidados - psicólogos, psiquiatras, delegados, etc. -, uma intensa exploração do lado patológico dos indivíduos acusados. Grande parte da fala dos especialistas constrói-se no sentido de evidenciar a perturbação mental dos foragidos, categorizando-os como psicopatas. Essa postura vai ao encontro da descontextualização do fenômeno da violência empreendida pelo programa. Os crimes pelos quais os indivíduos são acusados são mostrados como se surgissem do nada, como se fossem descolados de toda uma situação, de toda uma estrutura já institucionalizada que justamente é uma das responsáveis por criar indivíduos violentos.

A violência, nas esquetes do Linha Direta, nos é passada como algo que já nasce com a pessoa, algo congênito, enfim, uma patologia, que não tem qualquer relação com a sociedade e com a atuação dos governos, pois nunca é mostrada a influência que estes (sociedade e governo) têm na formação dessa violência presente no indivíduo. E, jamais, nos é mostrada a violência que esta sociedade e estes governos praticam contra esses (e muitos outros) cidadãos, negando-lhes os instrumentos básicos de cidadania, como educação; moradia decente; direito à saúde, lazer, cultura; entre outras coisas as quais a população não tem direito em sua vivência. Então, segundo Morais (1990, p. 45), "Não temos o direito de esperar um comportamento brando por parte das pessoas em um espaço [urbano] que as aliena dos seus semelhantes e as expropria de si mesmas".

Um outro ponto que se faz importante abordar acerca do Linha Direta é o fato do programa se intrometer numa área que não é, oficialmente, de sua alçada. O campo jornalístico atua como um mediador sobre todos os outros campos sociais (RODRIGUES, 2000), interagindo com eles, numa relação que envolve cumplicidades e tensionamentos. Essa interação do campo das mídias com os outros campos sociais é ainda potencializada pelo fenômeno 
da midiatização e pela informatização de grande parte dos sistemas que regem o funcionamento das coisas, conferindo velocidade e visibilidade aos acontecimentos.

No entanto, nem sempre vemos somente benefícios como conseqüência para essa penetração do jornalismo nas outras esferas da sociedade. Quando a exposição à mídia confere agilidade, por exemplo, a determinados processos de proteção ao consumidor - processos corriqueiros, mas que, certamente, levariam anos sem a interferência do sistema midiático - tem-se, então, o lado positivo dessa dinamização. No entanto, quando o jornalismo passa por cima do andamento da Justiça (sendo ele lento ou não), que tem um ordenamento prévio a seguir, tais como fatos a apurar, provas a analisar, testemunhas a depor, etc., ele pode, muitas vezes, na ânsia pela velocidade no fluxo dos acontecimentos, tão cara à lógica do espetáculo televisivo e da notícia como mercadoria, condenar ou absolver antecipadamente um indivíduo. Segundo Rodrigues (2000, p. 205):

Como exemplos [...] destacam-se as questões [...] suscitadas pelas relações do campo dos media com o campo jurídico a propósito da revelação de elementos de processos não transitados em julgado, da divulgação dos nomes de réus antes de sua condenação pelos tribunais, da revelação das fontes.

É exatamente isso que faz o Linha Direta quando incita, na audiência, a caça aos fugitivos mostrados no programa. Indivíduos que, embora algumas vezes ainda não tenham sido oficialmente julgados pela Justiça, têm seus rostos exibidos para todo o país e a história do crime ao qual supostamente estão ligados contada, pela emissora, de um modo, como já vimos, parcial e unilateral. Pela perspectiva do espetáculo televisivo, que vê na notícia a matéria-prima para o lucro, o jornalismo pode atuar sobre os outros campos, muitas vezes, tendo a emoção e o sentimentalismo exacerbados como base de seu discurso e a velocidade desmedida como artifício de seu exercício.

\section{Considerações finais}

Este artigo é fruto de reflexões advindas de uma pesquisa ${ }^{21}$ maior, ainda em desenvolvimento, guiada pela luz da Teoria da Recepção, ou seja, cujo foco se dá exatamente sobre o público telespectador do programa Linha Direta. Após a estratégia metodológica utilizada na investigação, envolvendo uma exploração inicial com os receptores a partir de questionários fechados ${ }^{22}$ e entrevista semiestruturada em profundidade, ${ }^{23}$ já é possível afirmar - mesmo que preliminarmente, pois ainda precisa ser concluída a terceira e última fase da estratégia metodológica adotada na pesquisa, as videoconversas,${ }^{24}$ bem como ainda falta a compilação total dos dados pesquisados -, que para grande parte dos telespectadores do Linha Direta o programa tem sim uma atuação que deve ser respeitada, na medida em que, para esses receptores, a polícia e a justiça de nosso país são lentas e têm uma atividade em muitos casos ineficaz, que não consegue atender a toda a demanda existente. O programa, ao dar visibilidade a esses crimes até então impunes, sem resposta e, muitas vezes, sequer compreendidos, agiria de maneira positiva na visão de boa parte do público investigado, no sentido de proporcionar a denúncia anônima e a prisão dos foragidos, seja lá em qual parte do país eles estejam. O objetivo do programa é atingido justamente quando o alcance e a penetrabilidade da televisão possibilitam que a população de um país de proporções continentais como o Brasil fique ciente de um crime ocorrido seja no norte ou no sul da nação.

Como pudemos perceber ao longo da discussão posta em prática, os contornos da cidadania que o Linha Direta procura empreender adquirem sim alguns traços de mercadoria, mas seria precipitado de nossa parte simplesmente afirmar que o programa não exerce nenhum tipo de benefício, que sua causa é meramente mercadológica. Basta que recorramos à voz dos telespectadores para percebermos claramente que os traços constitutivos do programa são ambíguos e difíceis de serem enquadrados numa caracterização rígida. Devemos levar em conta que são 415 fugitivos

\footnotetext{
21 "Violência e cidadania na sociedade midiatizada: o programa Linha Direta sob a ótica da recepção ", desenvolvida pelo autor deste artigo no mestrado em Ciências da Comunicação da Universidade do Vale do Rio dos Sinos - Unisinos desde março de 2006.

22 Foram pesquisados 30 sujeitos-telespectadores do programa, divididos em 3 grupos, que responderam a um questionário com 13 perguntas fechadas e 3 abertas.

23 Foram pesquisados 7 sujeitos-telespectadores (selecionado dentre os 30 participantes da primeira fase), que responderam a uma entrevista semi-estruturada com, em média, 50 perguntas.

24 Nesta fase são mostrados trechos do programa para debates entre os grupos investigados, mediados pelo pesquisador.
} 
capturados. Mesmo que nem todo o contingente tenha sido preso por meio unicamente do programa, é um número que deve sim ser considerado, principalmente tendo-se em mente a dor das famílias que, após anos e anos sem receber nenhum tipo de resposta das autoridades competentes, resolvem contar suas histórias à produção do programa, na ânsia de obter alguma punição para o acusado ou, muitas vezes, na expectativa de ao menos entender os motivos do crime ou encontrar os corpos de seus entes que até então se encontram desaparecidos.

O que pretendemos enfatizar, no entanto, é que nem sempre os fins justificam os meios. A finalidade do programa e da proposta do Linha Direta - e, por que não dizer, também da rede Globo, cujo slogan "cidadania, a gente vê por aqui" é cotidianamente exposto em sua grade - podem até ser atingidos, mas os recursos que são utilizados para que essa finalidade seja efetivada são passíveis de críticas, por se inscreverem na lógica do espetáculo e da notícia, do fato jornalístico, como uma mercadoria, que adquire mais ou menos valor de mercado dependendo do seu grau de emoção, de sensacional, de extravagância.

De certo que se o programa não tivesse bons índices de audiência, não agregasse valor mercadológico ao seu intervalo comercial, enfim, não gerasse lucro para a Rede Globo, ele já teria sido retirado da grade. O Linha Direta não só traz dividendos como, também, respaldo, prestígio, por ser uma atração de "utilidade pública" dentro da programação da maior emissora de televisão do país. Crimes de colarinho branco, corrupção de "figurões" de Brasília, assassinatos e outros crimes políticos são evitados pela produção do Linha Direta, numa clara postura de que os interesses da emissora - e sua cumplicidade com boa parte dos poderosos do Estado - vêm sempre em primeiro lugar. Mas por acaso a cidadania também não é, corriqueiramente, dilacerada pelos crimes ocorridos no alto escalão da sociedade ou a violência que a corrompe só se localiza no universo dos menos favorecidos?

Enfim, se o programa atua em prol da cidadania, no combate à violência e à criminalidade, ou se não passa de mercadoria, construída sob a égide do capitalismo e da perspectiva da notícia como lucro, o que fica claro é que cada vez mais o campo das mídias, tendo o jornalismo como protagonista, participa de forma mais enfática nos outros campos sociais, atuando como configurador dessas outras instâncias sociais, agindo inclusive sobre as demandas coletivas. A cidadania agora, além de midiatizada, estaria, também, sendo espetacularizada?

\section{Referências}

ANGRIMANI, Danilo. Espreme que sai sangue: um estudo do sensacionalismo na imprensa. São Paulo: Summus, 1995.

BORELLI, Sílvia; PRIOLLI, Gabriel (Org.). A deusa ferida: por que a Rede Globo não é mais a campeã absoluta de audiência. São Paulo: Summus, 2000.

BOURDIEU, Pierre. Sobre a televisão. Rio de Janeiro: Zahar, 1997.

BRITTOS, Valério Cruz (Org.). Os 50 anos da TV brasileira e a fase da multiplicidade da oferta. Observatório-Revista do Obercom, Lisboa, n. 1, p. 47-59, maio, 2000.

\section{Comunicação na fase da multiplicidade} da oferta. Porto Alegre: Nova Prova, 2006.

BUCCI, Eugênio. Videologias: ensaios sobre televisão. São Paulo: Boitempo, 2004.

CAPPARELli, Sérgio; LIMA, Venício A. de. Comunicação e televisão: desafios da pósglobalização. São Paulo: Hacker, 2004.

CARVALHO, José Murilo. Cidadania no Brasil: o longo caminho. Rio de Janeiro: Civilização Brasileira, 2002.

CASTEL, Robert. As metamorfoses da questão social. Rio de Janeiro: Vozes, 1998.

DUARTE, Elisabeth Bastos. Televisão: ensaios metodológicos. Porto Alegre: Sulina, 2004.

IANNI, Octávio. A sociedade global. Rio de Janeiro: Civilização Brasileira, 1992.

A era do globalismo. Rio de Janeiro: Civilização Brasileira, 1996.

KELLNER, Douglas. Cultura da mídia e triunfo do espetáculo. In: MORAES, Denis (Org.). Sociedade midiatizada. Rio de Janeiro: Mauad, 2006. p. 119-147.

MACHADO, Arlindo. Pode-se falar em gêneros na televisão? Revista Famecos, Porto Alegre, n. 10, jan-jun,1999. Disponível em: <http://www.pucrs.br/famecos/pos/revfamecos/10/arlindo.pdf $>$. Acesso em: 09 out. 2007.

MATA, Maria Cristina. De la cultura masiva a la cultura mediática. Revista Diálogos de 1a Comunicación, Lima, n. 56, p. 80-89, out., 1999. 
De la presencia a la exclusión. La obliteración del conflicto y el poder em la escena mediática. Revista Diálogos de la Comunicación, Lima, n. 59-60, p. 166-173, out., 2000.

MENDONÇA, Kleber. A punição pela audiência: um estudo do Linha Direta. Rio de Janeiro: Quartet, 2002.

MORAIS, Regis. O que é violência urbana. São Paulo: Brasiliense, 1990.

OLIVEIRA, J. M. Paquete. A democracia, os "media" e a "censura oculta". In: PERUZZO, C. M. K.; ALMEIDA, Fernando (Org.). Comunicação para a cidadania. São Paulo: INTERCOM; Salvador: UNEB, 2003. p. 52-71.

OROZCO GOMÉZ, Guillermo. Los estudios de recepción: de um modo de investigar, a uma moda, y de ahí a muchos modos. InTexto, Porto Alegre: UFRGS, n. 9. 2004. Disponível em: <http:// www.intexto.ufrgs.br/n9/a-n9a6.html>. Acesso em: 15 nov. 2006.

PAIS, José Machado. Ganchos, tachos e biscates. Porto: Âmbar, 2001.

RODRIGUES, Adriano. A gênese do campo dos media. In: SANTANA, R. N. Monteiro (Org.). Reflexões sobre o mundo contemporâneo. Rio de Janeiro: Revan, 2000. p. 201-210.
SODRÉ, Muniz. Antropológica do espelho: uma teoria da comunicação linear e em rede. Rio de Janeiro: Vozes, 2002.

SANTOS, Boaventura de Sousa. Pela mão de Alice: o social e o político na pós-modernidade. Porto: Afrontamento, 1994.

A crítica da razão indolente: contra o desperdício da experiência. São Paulo: Cortez, 2002.

SANTOS, José Vicente Tavares dos. Novos processos sociais globais e violência. Violência e mal estar na sociedade, São Paulo em Perspectiva, São Paulo, v. 13, n. 3, p. 18-23, jul./ set. 1999.

Microfísica da violência, uma questão social mundial. Revista da SBPC Ciência e Cultura, São Paulo, ano 54, n. 1, p. 22-34, jul. 2002.

Recebido em: 08/04/2007 Received in: 04/08/2007 Aceito em: 14/05/2007 Accepted in: 05/14/2007 